\title{
"Not as a White Man, Not as a Sojourner"

\author{
James A. Teit and the Fight for Native Rights in \\ British Columbia, 1884-1922
}

\author{
Peter Campbell
}

James Alexander Teit was born in the Shetland Islands of Scotland on 15 April 1864. ${ }^{1}$ He left his parents, who were successful shopkeepers, at the age of 19, and emigrated to North America. In March 1884 he took up residence in the tiny community of Spence's Bridge, in the southern interior of British Columbia. ${ }^{2}$ Teit married a Nlaka'pamux (Thompson River) woman, Lucy Antko, in 1892, who died of tuberculosis in March 1899. On 15 March 1904 he married Leonie J. Morens, a native of Spence's Bridge. The couple had five children - sons Eric, Magnus, Sigurd, and Thor, and a daughter Inga. Teit spent almost his entire life in British Columbia in Spence's Bridge, except for the period 1887 to 1892 , during which time he worked primarily as a coalminer in Nanaimo. During the last three years of Teit's life, from 1919 to 1922 , the family lived in Merritt, B.C., although he continued to do much of his work in Spence's Bridge. ${ }^{3}$

James Teit began his study of native people the year he arrived in Spence's Bridge and continued his work as one of Canada's leading anthropologists until his death on 30 October $1922 .{ }^{4}$ Even in his own day Teit was a

1 Teit's family name was Tait, but he changed it to Teit apparently because he wanted his name to reflect the Nordic roots of his native Shetland Islands. See Don Bunyan, "James Teit - Pioneer Anthropologist," Heritage West, Vol. 5, no. 3 (Fall 1981), 21.

2 Teit's uncle John Murray ran a store in Spence's Bridge and traded with the native people in the area. Katharine Howes and Pat Lean, "An Interview with Inga Teit Perkin, Daughter of noted Ethnologist James A. Teit," Nicola Valley Historical Quarterly, Vol. 2, no. 2 (April 1979), 4.

3 National Archives of Canada (NAC), Department of Indian Affairs (DIA), RG 10, Vol. 8064, File 901/30-1-14; G. E. Sharpe, Indian Agent, to Major D.M. MacKay, Indian Commissioner for British Columbia, 5 August 1946, 6 August 1946.

4 Teit was what James Clifford calls a "describer-translator of custom," not a "builder of general theories about humanity." He read little anthropological theory, and did not advance what Clifford calls a "unified interpretive hypothesis." Nor did he, like later participantobservers such as Margaret Mead or E. E. Evans-Pritchard, 'scientifically' analyze his own role as collector and interpreter of other cultures. Yet James Teit entered into and understood the social organization, material culture, spirituality, and world view of the 
controversial figure. Local whites whispered about this white man living with an Indian woman. As a non-native, he had to gain the confidence of native people whose entire way of life was under assault by a racist state and racist whites who occupied Indian lands, destroyed the native economy, and often worked to destroy native languages and cultures. ${ }^{5}$ As a Marxist and long-time member of the Socialist Party of Canada (SPC), Teit was a socialist in a rapidly developing frontier economy in which capital was king, and socialism perceived as a dire threat to unbridled pursuit of the main chance.

Although James Teit has been a well known figure in anthropological literature for many years, the extent and complexity of his involvement in the native rights movement has not received as much attention. The treatments of Teit's political role that do exist tend to marginalize his contribution, and generally fail to assess the relationship between his political activism and his anthropological work. No assessment has been made of the impact of Teit's socialism on his political or anthropological work, or on the way in which his association with the Socialist Party of Canada affected his view of native people. Even more importantly, perhaps, Teit has been, either directly or indirectly, associated with other 'white friends of the Indians,' a characterization that lends itself to negative interpretations of Teit's character and motivations.

That negative side existed, as it does in all human beings, but it will be argued in this paper that the overall assessment of James Teit's life and work should come from the native leaders with whom he worked. The native leaders who worked with Teit, especially Peter Kelly and Andrew Paull, considered him to be a brother and one of their most valued allies. ${ }^{6}$ To them, what James Teit did was much more important than who James Teit was. Their philosophy was that of George Manuel, who has observed that "race is not a barrier to the scholar who is also a sharer, a teacher, and a friend." "

Nlaka'pamux as well as any European has ever understood any native people. Only an essentialist defence of anthropology as 'science' and 'profession' would deny that James Teit was an anthropologist in the most meaningful sense of the term. See James Clifford, The Predicament of Culture: Twentieth-Century Ethnography, Literature, and Art (Cambridge, Massachusetts 1988), 27-8.

5 Teit himself was involved in the defence of cultural practices such as the potlatch, and sought to overturn the federal government ban on it. A great deal has been written on the question, including Forrest E. LaViolette, The Struggle for Survival: Indian Cultures and the Protestant Ethic in British Columbia (Toronto 1973); and more recently, Douglas Cole and Ira Chaikin, An Iron Hand Upon the People: The Law Against the Potlatch on the Northwest Coast (Vancouver 1990).

6 For Kelly, see Alan Morley, Roar of the Breakers: A Biography of Peter Kelly (Toronto 1967); for Paull, see E. Palmer Patterson II, "Andrew Paull (1892-1959): Finding a Voice for the 'New Indian'," The Western Canadian Journal of Anthropology, Vol. 6, no. 2 (1976).

7 George Manuel and Michael Posluns, The Fourth World: An Indian Reality (Don Mills, Ontario 1974), 161. 
"Not as a White Man" 39

James Teit played a key role in the native rights movement in British Columbia, and he spearheaded the attempt to bring greater unity to the movement by struggling for the unity of natives and non-natives, and the unity of the interior and coast native peoples. It is simply impossible to understand the history of the native rights movement in British Columbia in the first two decades of the twentieth century without understanding the role played by James Teit. In time Teit's importance was recognized by officials in the Department of Indian Affairs, and they attempted to co-opt him. In that endeavour they appear to have been partially successful, but not successful enough to tarnish Teit's contribution in the eyes of his native friends, or to call into question the many years of diligent service that he rendered to the native people of British Columbia. James Teit will almost certainly remain a controversial figure for many years, but by appreciating him as a whole human being - as family man, anthropologist, Marxian socialist, ethnobotanist, linguist, and fighter for native people - it is possible to understand why his native friends, rightly or wrongly, came to consider him one of their own.

\section{James Teit As Anthropologist}

In order to understand James Teit's great knowledge of native people and his work with them, it is necessary to establish his background as an anthropologist. Within a year of his arrival in British Columbia Teit was studying population decline in native societies. Even more significant, however, was Teit's awareness of the psychological impact of population decline on the native people themselves. In 1900 he noted: "The belief that they are doomed to extinction seems to have a depressing effect on some of the Indians. At almost any gathering where chiefs or leading men speak, this sad, haunting belief is sure to be referred to." 8 Ten years before he became an associate of Franz Boas, therefore, Teit was not only studying fast-disappearing elements of pre-contact culture, but was engaged by the contemporary problems of native people as well.

As indicated in many of his letters to Franz Boas and Edward Sapir, however, Teit was motivated not so much by a belief that the 'race' was dying, as by the fact that individual native elders, who had the knowledge of pre- and early-contact culture, were dying. In a very real sense Teit and his native informants were working together in an attempt to preserve as much of native culture as possible. In June 1908, when James Teit was studying the linguistic affiliations between the Interior Salish of British Columbia and the native people of Washington State, he observed that the people on the Colville 
Reservation "have become very interested and are desirous to give me all the information they can. They are glad that I have visited them, and also to know their history is to be recorded as the white man's is." Teit found that some Yakima and Nez Percé felt the same way. Teit also discovered that many young native people were not much interested in the knowledge of their elders concerning pre-contact native society. ${ }^{9}$ Teit was not native, but he showed a genuine interest in the ideas of native people, male and female, and was willing to sit and listen to them for hours and days at a time. ${ }^{10}$

In a day and age when the great majority of white anthropologists did not live with native people or speak their language, and white people in general almost never took the time to listen to what native people were saying, James Teit was a notable exception. Franz Boas noted on his first trip to Spence's Bridge in 1894 that Teit "lives with a number of Indians." It It appears that Teit lived in Spence's Bridge itself from 1884 to 1887, in Nanaimo and other mining towns from 1887 to 1892 , and then moved into or near the Indian community when he married Lucy Antko. From 1904 on, he did not again actually live with native people. Unlike Boas, however, who did not usually live with native people when doing field work, Teit did often live with native people when doing his research, although he also stayed in hotels, especially when in the United States. In addition, Teit slept in Indian tents when he acted as a guide for big game hunters from Canada, the United States, and Europe. ${ }^{12}$

Franz Boas was also impressed with the fact that Teit was thoroughly competent in the language of the Nlaka'pamux. In time he also learned to speak Lillooet and Shuswap, the other major Interior Salish dialects. ${ }^{13} \mathrm{He}$ compiled vocabularies of the other Interior Salish dialects, including Okanagan, Sans Poil, Colville Lake, Spokane, Kalispel, Pend d'Oreille, Coeur d'Alene, and Columbia. He was able to do this even among Athapaskan-speaking peoples, although he had no formal training in linguis-

9 American Philosophical Society (APS), Philadelphia, Pennsylvania, Franz Boas Papers (FBP), B:B61, James Teit to Franz Boas, 17 June 1908. Homer G. Barnett notes that one of the results of the attempt to 'civilize' native people in the Pacific Northwest was the generation gap between young and old, which led young native people to scoff at the 'superstitions' of their elders. See Barnett, Indian Shakers: A Messianic Cult of the Pacific Northwest (Carbondale 1957), 338

10 As Wendy Wickwire points out, Teit stood out among anthropologists of his day for the "sensitive and full" treatment he provided of women's issues. See her "Women in Ethnography: The Research of James A. Teit," Ethnohistory, Vol. 40, no. 4 (Fall 1993), 556.

11 "Boas to Dear Wife," North Bend, 21 September 1894; quoted in Ronald P. Rohner, The Ethnography of Franz Boas (Chicago 1969), 139.

12 Judith Judd Banks, "Comparative Biographies of Two British Columbia Anthropologists: Charles Hill-Tout and James A. Teit," (Vancouver: University of British Columbia M.A. Thesis, 1970), 96.

13 Franz Boas, "James A. Teit," Journal of American Folk-Lore, Vol. 36 (1923), 102-3. 
tics. ${ }^{14} \mathrm{He}$ collected Cree tales, spoke Chinook "pidgin," and worked among the Kutenai. According to the Western Clarion, Teit also spoke French, Norwegian, and Danish in addition to English. ${ }^{15}$

In spite of his long association with Franz Boas, it is very problematic, as a number of writers have done, to imply a marked similarity in their views by characterizing Teit as Boas' associate. The two men did share a common interest in human societies, culture, and cultural change. They were both champions of inductive reasoning, working from fact to theory, not from theory to fact. Yet there were pronounced differences between the two men. There is little evidence to suggest, for example, that Teit shared Boas's belief that "the widespread occurrence of diffusion invalidates theories of cultural evolution."16 Teit tended to see Indian cultures as self-contained, and native languages as existing, or at least to have existed, in relatively pure forms. He was more prone than Boas to a belief in unilinear cultural evolution, a tendency no doubt reinforced by his reading of the Socialist Party's paper The Western Clarion. The great majority of the writers in the Clarion in the early twentieth century still looked at human evolution in terms of Lewis Henry Morgan's evolutionary categories - savagery, barbarism, and civilization. ${ }^{17}$ Writers in the paper talked about "man's ceaseless evolution from the simple to the complex," and almost always cast this evolution in terms of organic growth, a perspective they derived from thinkers as varied as Friedrich Engels, Herbert Spencer, and Jack London. ${ }^{18}$ While there is no formal recognition of this influence in Teit's letters, it does appear in subtle forms. For example, Teit opposed the federal government's ban on the potlatch in part because he believed that it might eventually die of "natural causes" in any event. ${ }^{19}$

There is no evidence, however, to suggest that Teit saw native societies as somehow proto-socialist - he was concerned with native societies in and of themselves. For most members of the Socialist Party, native societies were not studied in and of themselves, but rather were taken as examples of "primitive communism," that is, societies exhibiting some of the characteristics of

14 Regna Darnell, Edward Sapir: Linguist, Anthropologist, Humanist (Berkeley 1990), 72.

15 "Obituary," Western Clarion, 16 November 1922. He also had some knowledge of German, Spanish, and Dutch.

16 Rohner, The Ethnography of Franz Boas, xvii

17 See, for example, "The Evolution Of Human Society," Western Clarion, 25 May 1912.

18 This quotation is from "Organic Evolution And Human Progress," Western Clarion, 12 October 1912.

19 Canadian Museum of Civilization (CMC), Edward Sapir Papers (ESP), I-A-236M, Box 430, Folder \#4, James A. Teit 1913-14, Teit to Sapir, 5 August 1914. 
the society of the socialist future. ${ }^{20}$ On the other hand, Teit was like his fellow SPCers in that he rarely, if ever, speculated about the future characteristics of native societies in Canada, in very much the way that members of the SPC refused to describe what a future socialist society would be like. The workers themselves would create that society, and Teit seems to have taken a very similar attitude toward native people - once he had helped them attain their rights and a land base capable of providing economic self-sufficiency, it would be up to them to organize their own society. Franz Boas, by way of contrast, was speculating as early as 1889 that the Kwakiutl might survive as a people if the Canadian government could make "independent producers out of them." 21

It is unlikely that Teit's ideas concerning the broad sweep of human history were of much importance to the native people he worked with. What they did appreciate was that Teit, unlike Boas, never presumed to tell them how they should organize their social and economic lives. As a result, Teit played a leading role in convincing native people in British Columbia that they had some trustworthy non-native allies, and gave the work anthropologists were doing a degree of acceptance it otherwise would not have had. $\mathrm{He}$ showed great concern for native people as individuals and treated both material and spiritual aspects of the culture with respect. As a political activist, he fought to increase native landholdings and their resource base, but left it up to native people themselves to decide how their lands and resources would be utilized.

\section{James Teit As Political Activist}

The history of the fight for native rights in British Columbia has been recounted many times and will not be retold in this paper. ${ }^{22} I$ will begin with Teit's involvement in the years 1908-16, describe the formation of the Allied Tribes, assess Teit's role in the years 1916-22, and end with the appearance of the leaders of the native rights movement before a committee of the Canadian Senate and House of Commons in 1927. Central to the analysis will be exploring Teit's effectiveness in representing Indian interests, and assessing the extent to which Teit's employment by, and relationship with, the Department of Indian Affairs compromised his ability to do that. In addition, the relationship between Teit's political activism and his continuing efforts to complete his anthropological work will be examined.

20 See "Lo, The Poor Indian," Western Clarion, 5 June 1909.

21 Rohner, The Ethnography of Franz Boas, 13.

22 For the most comprehensive treatment see Paul Tennant, Aboriginal Peoples and Politics: The Indian Land Question in British Columbia, 1849-1989 (Vancouver 1990). 
By the time James Teit became involved in the struggle for native rights native people had been fighting their own battles for decades. ${ }^{23}$ Organized native resistance in British Columbia related to the land question is generally traced to the 1874 petition of Lower Fraser chiefs opposing the Dominion Order-in-Council of 1873, which called for 80 acres of land to be alloted to each Indian family of five. In 1887 the Nisga' a sent delegations to Victoria and Ottawa to petition for their rights. The natives of the B.C. interior began organizing in the early 1900s. In 1906 interior chiefs Basil David and John Chillihitza joined Squamish leader Joseph Capilano on a trip to England to present a petition to King Edward VII.

Teit first became actively involved in native protest in 1908. While on a trip to the United States Teit wrote to Franz Boas from Idaho:

I may say that in southern $\mathrm{BC}$ there is considerable disatisfaction [sic] \& unrest amongst the Indians at present, the settling up of the country \& changing of conditions is restricting the Indians more \& more to their small reserves, \&c. They are also of the opinion they are very much neglected \& kept in an inferior condition. When I return home about 30 Thompson, Shuswap \& Okanagan chiefs are to meet at Spences [sic] Bridge to hold a big 'talk' preliminary to sending a big 'paper' to Ottawa recounting their grievances. ${ }^{24}$

Teit either knew about this meeting before he left B.C., or was informed about it while in the United States. It is significant that the meeting was not to be held until Teit's return. While the initiative for this meeting appears to have come from native leaders, it is evident that Teit had already become an important figure in the native rights movement.

Native organizing really got off the ground in 1909, when the Interior tribes, with the help of Teit, formed what is usually called the Interior Tribes of British Columbia. ${ }^{25}$ In the same year the Indian Rights Association was organized by north coast and Coast Salish leaders. In March 1910 the Friends of the Indians of British Columbia, a largely Anglican group, was created in order to support Indian political activity. A.E. O'Meara, who would become a figure of great controversy in the native rights movement, was appointed legal counsel of the organization. ${ }^{26}$

23 Native people were fighting their own battles, but were not fighting them alone. Church missionaries were involved in the native rights movement from the beginning, acting as leaders, guides, and advisors.

24 APS, FBP, B:B61, Teit to Boas, 23 May 1908.

25 Tennant, Aboriginal Peoples and Politics, 87.

26 A.E. O'Meara was born in Port Hope, Ontario in 1859. He received his B.A. from the University of Toronto in 1882, and was called to the bar in 1885 . In 1906 he became an Anglican priest. See E. Palmer Patterson II, "Arthur E. O'Meara, Friend of the Indians," Pacific Northwest Quarterly, Vol. 58, no. 2 (April 1967), 91-2. 
The composition of these various organizations holds one of the keys to the importance of James Teit, and why he should not be seen as just another white friend of the Indians. A.E. O'Meara did work for the Indian Rights Association, but was not on the executive committee. The Reverend C.M. Tate, a missionary, was both chairman and secretary of the Indian Rights Association, but was not associated with the Interior Tribes. ${ }^{27}$ James Teit was on the executive committee of the Indian Rights Association, and the leading organizer of the Interior Tribes. In spite of his central role, however, Teit was very principled in carrying out the policies of the native leaders. Given that Teit appears to have been the only non-native on the twelve-person executive of the Indian Rights Association, his involvement very much depended on the approval of the native members. Differences notwithstanding, the years 1909-10 represent an important moment of cooperation, with native and non-native leaders providing their contributions in unique ways. No leader, however, made a greater contribution than James Teit.

James Teit's own correspondence suggests that, in spite of the loose structure of these organizations, and differences among natives peoples of the coast and the interior, and their white allies, these organizations were quite active. On 1 March 1911, following a recent meeting in Kamloops, James Teit, acting as secretary, accompanied a delegation of interior chiefs to the coast Indian convention in Victoria, where they interviewed representatives of the B.C. government. ${ }^{28}$ In November 1911 Teit wrote to Boas, noting that: "The Coast Indians are anxious that I take two or three of the strongest men of the Interior chiefs, and go as a deputation from the Indian Rights Association of B.C. to the Dom. gov. at Ottawa on the land question \& other grievances of the Indians..." In effect, the coast leaders trusted a white man and the interior leaders to represent them in talks with the federal government, indicating a strong unity of purpose.

The tribes of the interior may have been loosely affiliated, but they were well enough organized to present Prime Minister Sir Robert Borden with a petition at Kamloops in January $1912 .{ }^{29}$ In July 1912 some 450 native people met at Spence's Bridge, a meeting also attended by a "special commissioner" of the federal government. People came from all the interior tribes, as well as the Carrier, Chilcotin, and Stalo. There were several south coast chiefs in attendance, and even one representative each of the Spokane and Coeur

27 CMC, ESP, I-A-236M, Box 430, Folder \#4, James A. Teit 1913-14, Teit to Sapir, 18 December 1913.

28 APS, FBP, B:B61, Teit to Boas, 1 February 1911; Teit to Boas, 12 March 1911.

29 Darcy Anne Mitchell, "The Allied Tribes of British Columbia: A Study in Pressure Group Behaviour," (Vancouver: University of British Columbia M.A. Thesis, 1977), 29.

30 CMC, ESP, I-A-236M, Box 430, Folder \#3, James A. Teit 1911-12, Teit to Sapir, 7 July 1912; 2 August 1912. 
d'Alene. ${ }^{30}$ The culture of native people in the B.C. interior was under assault at this time, but native people were fighting back and organizing. James Teit helped, both with the organizing of meetings and protest in the interior, and in coordinating the political activities of the coast Indians and the Indians of the interior. ${ }^{31}$ But why, exactly, was he doing this?

Teit's motives for becoming involved in the native rights movement were a combination of altruism and self-interest. His early interest in 1908 would appear to have been motivated by the desires of native people themselves. This interest was compounded by his observations on his trip to the United States in the spring and summer of that year. On that trip Teit realized that native people in America were in some ways better off than native people in the B.C. interior, and genuinely wanted to make their lives better. He also wanted to defend native people from the Canadian and provincial governments, Christian missionaries, and whites trying to take away the land of native peoples.

By 1911, however, there was another reason. Even though Teit was probably the most trusted white anthropologist in British Columbia, there were still many native people who either refused to cooperate with him, or were hesitant to. This was not just because Teit was non-native, or because native people disliked his methods: Teit was opposed by church leaders, both white and native, in part because he forcefully opposed the federal government's anti-potlatch law. Supporters of the law banning the potlatch included native leaders such as Peter Kelly. There were many natives, as well as whites, who opposed the preservation and valorization of 'traditional' native culture. In attempting to blunt that opposition Teit quite consciously recognized that his political work "has given me greater influence than ever with all the Indians of the country, and this may be used to good advantage in ethnological work whether done by myself or by others introduced by me." 32 Yet even as he became more heavily involved in political work, Teit continually regretted the time it took away from his work as an anthropologist. Interestingly, whatever sense Teit had of his own historical importance was almost entirely tied to his anthropological work, not his political activism. Teit sensed his control over the preservation of pre-contact native artifacts and culture, but made no claim to being able to control the future of native people.

The source of that belief may be related to his long-standing membership in the Socialist Party of Canada. Indeed, Teit was contributing to social-

31 Alan Morley suggests that Teit played a key role in putting native ideas down on paper and forming a consensus of coast and interior opinion. See Morley, Roar of the Breakers, 107.

32 APS, FBP, B:B61, Teit to Boas, 16 February 1911. Six years later Teit also told Edward Sapir that settling the land question would make anthropological work easier. See CMC, ESP, I-A-236M, Box 430, Folder \#6, James A. Teit 1916-17, Teit to Sapir, 27 March 1917. 
ist publications in British Columbia and seeking subscribers for them before the Socialist Party was organized late in $1904 .{ }^{33}$ Teit was no doubt a marginal member of the SPC - in 1906 his major contribution to the party was a donation of money to the SPC's election campaign fund..$^{34}$ It is evident, however, that he supported the SPC's rigorous Marxism. In February 1908, just prior to his trip to the United States, Teit wrote to the Executive Committee of the Socialist Party in Vancouver, sending along $\$ 5.00$ to help fund a speaking tour of eastern Canada by two party members. Teit thought the trip would "result in much good to our cause," and signed off with the words "Yours for the Revolution always." ${ }^{35}$ In March 1909 he sent money to the SPC for copies of the Platform Constitution and Manifesto. Teit noted that the party's Manifesto "is clear and wastes no time with side issues," indicating that he supported the straight-ahead Marxism of the party. ${ }^{36}$

In the 1940s Indian Agent G.E. Sharpe noted that Teit "was interested in socialism, and often discussed it with his friends." ${ }^{37}$ There is no other evidence, however, to indicate if those friends were white, native, or both. Teit believed that native people were being "crushed" by the "general development of the capitalist system," but did not directly link the native struggle to overcome white oppression with the struggle of the workers to throw off the yoke of capitalism. ${ }^{38}$ Indeed, for a man imbued with a sense of "fair play for the aborigines" Teit's correspondence, with some exceptions, is remarkably free of moral condemnation of what has happened to native people. ${ }^{39} \mathrm{He}$ seems, in that sense, to have agreed with his fellow SPCers that the destruction of "primitive communism" was in some sense historically necessary, paving the way for capitalism, and ultimately, of course, socialism.

Teit seems to have done what he did because native people wanted it, not because he himself was outraged by what the Canadian state and racist whites had done to native people. He seems to have been driven by a commitment to fair play or justice, and helped native people out of a sense of moral

33 Banks, "Comparative Biographies of Two British Columbia Anthropologists," 52-4.

34 Western Clarion, 29 December 1906.

35 Western Clarion, 22 February 1908.

36 Western Clarion, 13 March 1909. The Clarion records correspondence from Teit on 11 April 1908, 5 December 1914, November 1917, June 1918, and 15 October 1918. The Clarion acknowledged subscription money from Teit on 19 February 1910 and 27 March 1915, and in November 1917. Election campaign contributions were acknowledged on 22 December 1906, 24 August 1907, and 30 October 1909.

37 NAC, DIA, RG 10, Vol. 8064, File 901/30-1-14, Sharpe to Major D.M. MacKay, 5 August 1946.

38 APS, FBP, B:B61, Teit to Boas, 23 February 1910.

39 CMC, ESP, I-A-236M, Box 430, Folder \#4, James A. Teit 1913-14, Teit to Sapir, 18 December 1913. 
earnestness. ${ }^{40}$ Teit, interestingly enough, does not seem to have considered the federal government as the enemy of native people, which some native people most certainly did. ${ }^{41} \mathrm{He}$ appears to have believed that the Department of Indian Affairs officials shared his commitment to fair play for native people. In effect, there is little indication that Teit perceived the government officials he worked with as part of the capitalist class he condemned for causing the war and suppressing the working class. Why Teit had this split perception does not emerge from his correspondence, but it is not unlike the world view of some other members of the Socialist Party. In addition, Teit shared another split perception of Marxian socialists of his day. Just as they tended to see workers under capitalism, and the workers of the socialist future, as being very different kinds of people, James Teit tended to see pre-contact native peoples and the native peoples of the future - even the native people of his own day - as somehow different kinds of people.

Even as he became heavily involved in the native rights movement James Teit remained very much engaged with the native people of the past. With the formation of the Allied Tribes, however, Teit's role of necessity became much more tied to the contemporary problems of native people. He participated in drawing up the long range plans of the Allied Tribes, co-wrote many pamphlets and petitions with Peter Kelly, and went to Ottawa, with native leaders, to present them to the federal government. Yet Teit always took 'service' positions such as secretary or special agent, while native leaders like Peter Kelly occupied positions such as chairman. While it is true that A.E. O'Meara tended to march to his own drummer, James Teit was rigorous to a fault in always consulting native people themselves before going ahead with a plan of action..$^{42}$

Perhaps Teit's own self-effacing manner has in part contributed to his being marginalized in most accounts of the formation of the Allied Tribes. That formation is usually dated from a North Vancouver conference organized in June 1916 by Peter Kelly and Andrew Paull. At this meeting A.E. O'Meara was retained as counsel, Peter Kelly was named chairman, and James Teit became the secretary of the executive committee.$^{43}$ It is now taken as fact, however, that Kelly and Paull were the key organizers and leaders of the Allied Tribes, and the contribution of the interior chiefs and James Teit

40 One cannot help but be struck by the sense of moral earnestness in Scottish socialists of this generation. Teit shared it with Bob Russell and J.B. McLachlan, much as he shared their love of the works of Robert Burns.

41 CMC, ESP, I-A-236M, Box 430, Folder \#6, James A. Teit 1916-17, Teit to Sapir, 27 March 1917.

42 See, for example, NAC, DIA, RG 10, Vol. 3820, File 59,335 Part 3, D.C. Scott to Sir James Lougheed, 1 October 1920.

43 Tennant, Aboriginal Peoples and Politics, 99. 
has been given little consideration. ${ }^{44}$ Teit's role was crucial, both in terms of his on-going support for native people, and his developing relationship with Deputy Superintendent General Duncan Campbell Scott and other Department of Indian Affairs (DIA) officials. ${ }^{45}$

Of more immediate importance in 1916, however, is that both native and non-native activists were organizing against the Royal Commission on Indian Affairs for the Province of British Columbia, appointed on 31 March 1913. The commission was commonly called the McKenna-McBride Commission after Special Commissioner J.A.J. McKenna, appointed by the federal government, and Premier McBride of British Columbia. The timing was significant, because in January 1913 the Nisga' a chiefs had decided to submit a petition to the Judicial Committee of the Privy Council. The petition was lodged with the Privy Council in May 1913, but was referred back to the Canadian government on 19 June 1913. A.E. O'Meara knew that a direct appeal to the Privy Council was unconstitutional, because such matters had to go through Canadian courts first. Yet he was able to convince Andrew Paull, Peter Kelly, and James Teit that a direct appeal was the best strategy. ${ }^{46}$ The strategy was not entirely misguided, because it did play a role in forcing the hand of the federal and provincial governments, and provided a rallying point for the formation of the Allied Tribes. ${ }^{47}$

One of the first tasks facing the Allied Tribes was responding to the findings of the McKenna-McBride Commission. To the frustration of native people and their allies, the Commission dealt almost exclusively with the size of existing reserves, and studiously avoided issues related to treaty rights and self-determination. ${ }^{48}$ It was James Teit and Peter Kelly, working together, who drew up the statement rejecting the report of the Commission and defending aboriginal rights. A month before the June 1916 conference in Vancouver at which the Indian Rights Association rejected the

44 Tennant, Aboriginal Peoples and Politics, 94-5; E. Brian Titley, A Narrow Vision: Duncan Campbell Scott and the Administration of Indian Affairs in Canada (Vancouver 1986), 144; J.R. Miller, Skyscrapers Hide the Heavens: A History of Indian-White Relations in Canada (Toronto 1989), 216.

45 Scott was Deputy Superintendent-General of Indian Affairs from 1913 to 1932 . For more on Scott see Titley, A Narrow Vision.

46 Titley, A Narrow Vision, 144.

47 Indeed, the argument that $O$ 'Meara 'conned' $B C$ 's native leaders into making a direct appeal to the Privy Council may be erroneous. In February 1910, Teit told Franz Boas that the native people wanted to take their case to the Privy Council. Given that the Friends of the Indians was not organized until March 1910, when O'Meara was appointed legal council, it is quite possible that this strategy was a native, not a white, one. APS, FBP, B:B61, Teit to Boas, 23 February 1910.

48 See Paul Tennant, Aboriginal Peoples and Politics, 88-9, and 96-8 for a more detailed treatment of the creation, composition, and findings of the Commission. 
Orders-in-Council ensuing from the McKenna-McBride Commission James Teit, on behalf of the interior Indians, had conveyed a similar position to Prime Minister Sir Robert Borden in no uncertain terms. Teit was secretary and interpreter of a delegation which made the following statement:

We see no real advantage to us in surrendering our rights for some lands to be added to our Reserves by the Royal Commission and some undefined benefits to be granted us by the Dominion Government ... we hereby state our determination that we will not lie down, but will push our case before the Privy Council of England by all means in our power. ${ }^{49}$

In effect, Teit and the interior chiefs had formally rejected the findings of the McKenna-McBride Commission a month before the Commission even released its report. Teit himself noted that the Vancouver conference "ended with the Indian Rights Association coming over to the position of the interior and Nass Indians and all making up their minds to work together." ${ }^{50}$ James Teit played a key role in the creation and work of the Allied Tribes, but there is nothing arrogant or self-serving about his interpretation of events. The coast Indians 'came over' to the interior position; for Teit unity was the important thing, not whose ideas were adopted or who should get the credit.

Teit's efforts to maintain unity between the coast and interior peoples, and between white and native activists, were threatened in the late war years by his uncompromising stand against conscription. The conscription debate, while in some senses a side issue, is important for two reasons. First of all, it was during this period that Teit came closest to linking his opposition to the role being played by the federal and provincial governments in the land rights dispute to his anger at the role played by Canadian leaders in the First World War. Perhaps more important, however, is the fact that the opposition of James Teit and Peter Kelly to conscription helps explain why the major histories of the native rights movement in B.C. are so silent on the 1917-18 years. ${ }^{51}$

By 1916 Teit was discussing socialism and the war in his letters with Edward Sapir, and sending him copies of the Western Clarion. ${ }^{52}$ As a socialist Teit, like Franz Boas and Edward Sapir, was repelled by the war, and considered it "a disgrace for peoples calling themselves Christian and civilized." The leaders of Canada, Britain, and the United States were hypocrites when

49 NAC, DIA, RG 10, Vol. 3822, File 59,335-2, James Teit to Sir Robert Borden on behalf of delegation of Interior Tribes, 9 May 1916.

50 CMC, ESP, I-A-236M, Box 430, Folder \#6, James A. Teit 1916-17, Teit to Sapir, 4 July 1916.

51 Paul Tennant, for example, jumps from June 1916 to March 1919 in his analysis of the activities of native people and their allies. Tennant, Aboriginal Peoples and Politics, 98-9.

52 CMC, ESP, Box 430, Folder \#6, James A. Teit 1916-17, Teit to Sapir, 20 December 1916. 
they claimed to be defending democracy. "Who ever heard," charged Teit, "of any modern capitalist class fighting for democracy?"53 By 1917 Teit was speaking out forcefully against conscription, perhaps inspired by articles in the Western Clarion and the increasing attention being paid by the B.C. media to anti-conscription speeches given by SPCers such as Bill Pritchard and Jack Kavanagh. ${ }^{54}$ On 17 November 1917 Teit and Peter Kelly, on behalf of the Allied Tribes, sent a wire to Sir Robert Borden opposing conscription. ${ }^{55}$ In the telegram Teit and Kelly noted that native people should not be conscripted because they did not have the citizenship rights of British subjects, and because the land question had not been settled. They referred to conscription as "enslavement," and claimed that any attempt to enforce the Military Service Act against Indians "would be forcibly resisted and probably cause bloodshed." ${ }_{6}$ The Kelly-Teit telegram appeared in the Victoria Daily Colonist on 20 November 1917. Three weeks later, in an article entitled "Indians Not Against Conscription Plan," the Duncan correspondent of the Victoria Daily Times reported that B.C. Indians had responded with great "indignation" to the Kelly-Teit telegram. A letter, signed by 17 chiefs, had been sent to the Military Service Branch in Ottawa, expressing disapproval of the telegram. Joe Capiele, chief of the Cowichan, said of the chiefs, "while they do not wish to go to fight, the idea of bloodshed never entered their minds, as they entertain only the kindliest feeling for the white people." 57

On the surface, therefore, it appeared that Kelly and Teit had seriously misrepresented the wishes of the native leaders themselves. On 12 December 1917, the day after the Daily Times article appeared, a letter by C.M. Tate, the General Secretary of the Indian Rights Association, appeared in the same paper. After pointing out that he and James Teit were two different people, Tate noted that "Mr. Teit never does anything rashly; and as he is a tried and trusted friend of the Indians throughout the province, you may rest assured that whatever he did was perfectly in order." Tate's most damning indictment of the article was his observation that the very same chiefs who sent the letter of protest to Ottawa had recently accompanied him to Victoria to protest against conscription. Tate also pointed out that Kelly was an Indian who authored the telegram with the support of the northern natives and the Nanaimo tribe. ${ }^{58}$

53 CMC, ESP, Box 430, Folder \#6, James A. Teit 1916-17, Teit to Sapir, 12 September 1917.

54 The Western Clarion is the only source of political news and opinion, apart from the daily press, that Teit seems to have read consistently in the years 1908-1922.

55 CMC, ESP, Box 430, Folder \#6, James A. Teit 1916-17, Teit to Sapir, 19 December 1917.

56 . Victoria Daily Colonist, 20 November 1917.

57 Victoria Daily Times, 11 December 1917.

58 Victoria Daily Times, 12 December 1917. 
Eight days later James Teit defended himself. He noted, in relation to conscription, that "I have not yet met a single Indian in favor of it." Teit had heard Indians "state in all seriousness that they will forcibly resist what they call their enslavement by conscription," and observed that many of them do not see how bloodshed can be avoided if they are forcibly conscripted. Teit also observed that the contents of the telegram had been endorsed by the chiefs at the meetings of various tribes. He concluded that he and Peter Kelly were trying to avoid trouble, not cause it, and that what trouble there was stemmed from the actions of the government. ${ }^{59}$

The crucial factor in all this was the federal election held on 17 December 1917. Why, for example, did the condemnation of Kelly and Teit hit the Victoria press three weeks after the telegram was published, and only six days before Borden's pro-conscription Union government was seeking a resounding mandate for its policies? The 11 December headline, "Indians Not Against Conscription Plan," was a blatant misrepresentation, given that Joe Capiele himself said he was opposed to conscription. The Unionists and their provincial allies were nervous, because in spite of the strong support for the war among some native people, the reality was that even voluntary enlistment among native people in British Columbia was significantly lower than that in most other areas of the country. ${ }^{60}$ One suspects that the agitation against Kelly and Teit was orchestrated by a white or native supporter of Borden and the Unionists.

If James Teit was not the only Canadian, he was certainly one of the few Canadians, to ever link socialist and native opposition to conscription. The result was both a strength and weakness in Teit's position. The strength was that James Teit expressed the very real opposition of native people to conscription, an opposition that has received little attention in histories of the First World War. Teit recognized, because of his anthropological work, that in pre-contact native societies the decision to go to war was voluntary ${ }^{61} \mathrm{He}$ respected native people who chose to fight, but was bitterly opposed to conscription. The weakness was that Teit and Kelly overstepped their bounds by talking about bloodshed, even though some native people may have agreed. It is almost certain that Teit's own hyperbole was picked up from the Western Clarion and the influence of anti-conscriptionists in the Socialist Party. The important point, however, is that the protests of Teit, Kelly, and

59 James Teit, "About the Indians," Victoria Daily Times, 20 December 1917.

60 Duncan Campbell Scott, "The Canadian Indians," Canada in the Great World War, Vol. III, Guarding the Channel Ports (Toronto 1919), 310. Scott makes much of BC native peoples, such as the Okanagan, who strongly supported the war, and downplays or entirely ignores those who did not. Fred Gaffen does much the same thing in his Forgotten Soldiers (Penticton 1985), 22.

61 CMC, ESP, Box 430, Folder \#6, James A. Teit 1916-17, Teit to Sapir, 19 December 1917. 
many organizations like the Allied Tribes led to the 17 January 1918 regulations passed by an Order-in-Council exempting Indians from conscription. ${ }^{62}$

In terms of Teit's involvement in the native rights movement, however, the results may have been much less salutary. A meeting of the Interior Tribes was held at Spence's Bridge on 6 December 1917, right in the middle of the conscription debate. The meeting drew up a resolution protesting against the report of the McKenna-McBride Commission, and the wording may be significant. The resolution, in setting out the claims of native people, seems more apologetic than usual. It makes a point of saying that "we do not want anything hurtful to the real interests of the white people," and assures whites that "in the future we shall be able to live and work with the white people as brothers and fellow-citizens." 63

Perhaps here we have at least a partial explanation for the lull in political activity in 1918. The year 1918 was not an eventful one for either Teit or the Allied Tribes. Teit was working occasionally for the Indians, and was not very involved in his anthropological work. Edward Sapir, Teit's employer at the Anthropology Section of the Department of Mines in Ottawa, did not have the funds to employ him. Instead, Teit did some prospecting, picked apples, took off hay, and dug potatoes. ${ }^{64}$ It is surely significant that this lull in Teit's activity in 1918 directly corresponded to a lull in the activity of the Allied Tribes, and is further proof of his importance.

In February 1919 the Executive Committee of the Allied Tribes met in Vancouver. Teit's role and the timing of the February 1919 meeting are significant. The executive meeting occurred one month before the B.C. legislature, in March 1919, passed the Indian Affairs Settlement Act, which empowered the provincial government to enter into further negotiations with the Indians. In spite of the fact that federal officials were wary of the provincial initiative, Premier Oliver asked the Allied Tribes to prepare a response to the McKenna-McBride report. As a result, the Allied Tribes met in Vancouver on 17-18 June, and the first general meeting of the Allied Tribes was held at Spence's Bridge on 24-25 June. At this meeting James Teit and Peter Kelly were appointed to prepare a list of grievances, which was adopted

62 On native people in the First World War see Gaffen, Forgotten Soldiers; James W. St. G. Walker, "Race and Recruitment in World War I: Enlistment of Visible Minorities in the Canadian Expeditionary Force," Canadian Historical Review, Vol. 70, no. 1 (1989), 1-26; and James Dempsey, "The Indians and World War One," Alberta History, Vol. 31, no. 3 (Summer 1983), 1-8

63 Quoted in LaViolette, The Struggle for Survival, 133. I have found no direct evidence that Teit was at this meeting, and the wording of the resolution indicates that he may not have been involved in its writing.

64 CMC, ESP, I-A-236M, Box 430, Folder \#7, James A. Teit 1918-19, Teit to Sapir, 30 October 1918. 
by the Executive Committee on 19 November $1919 .{ }^{65}$ In addition, according to Teit, the Tsimpshian and Kitikshian had allied themselves with the Allied Tribes at a recent conference held in Prince Rupert. ${ }^{66}$ In 1919, therefore, native rights activists were not just reacting to government initiatives. Native leaders took some initiative in setting aside political differences in a common effort to defend aboriginal rights and protest the possible cut-off of reserve lands without Indian consent. James Teit continued to play a central role, possibly inspired by his opposition to conscription and the building labour revolt of that year.

It is true, however, that in 1919 the extent of Teit's socialist and political activism was curtailed by the time taken up looking after his family. In March 1919 he wrote to Boas: "My sister in law who was my most valued friend here died of the 'flu' and was buried yesterday. My wife is very sick and I have a great deal to do looking after the children \&c." ${ }^{67}$ In May Leonie Teit was in the hospital in Merritt and two of the children had the mumps. In July, when Leonie Teit had appendicitis, Teit informed Boas that he had "been doing occasional work for the Allied Indian tribes in connection with their Land case." 68 It was clear, even to Boas, however, that Teit was becoming immersed in politics, noting that: "I am very anxious that you should not be drawn away from ethnological work ...." 69

The spring of 1920 found Teit more involved with the native rights movement than ever before. He made two trips to Ottawa with native delegations. On the first trip Teit left Merritt, B.C. on 10 March and returned on 16 May. On this trip he accompanied Peter Calder, George Matheson, Peter Kelly, and Basil David, with A.E. O'Meara arriving at a later date. The purpose of the delegation was to oppose Bill 13, the federal legislation introduced to enact the findings of the Royal Commission. ${ }^{70}$ At this time as well Teit was involved in drawing up a financial plan for the Allied Tribes with O'Meara and a Mr. McTavish, chairman of the Friends of the Indians. While in Ottawa the delegation published a letter in the Ottawa Journal, dated 5 May 1920, protesting against Bill 13. Teit appeared before the Senate Committee on Bill 13 and was also interviewed by Duncan Campbell Scott. Scott asked Teit to assist Chief Inspector Ditchburn with an inquiry into the Report of the Royal Commission. Teit did not accept the offer immediately.

65 Mitchell, "The Allied Tribes of British Columbia," 44.

66 APS, FBP, B:B61, Teit to Boas, 30 November 1919.

67 APS, FBP, B:B61, Teit to Boas, 16 March 1919.

68 APS, FBP, B:B61, Teit to Boas, 30 July 1919.

69 APS, FBP, B:B61, Teit to Boas, 6 August 1919.

70 Mitchell, "The Allied Tribes of British Columbia," 49. 
He consulted the native leaders, who approved, and then took the job. He was paid $\$ 200$ a month for a job which Scott thought might last six months. ${ }^{11}$

Scott's motives at this point are difficult to decipher. There is no doubt that he held a much higher opinion of Teit than of O'Meara, who was personally more abrasive and aggressive than Teit. ${ }^{72}$ Scott states that he has "come to have a very good opinion of Mr. Teit, not only as to his ability, but as to his trustworthiness, and I think his association with Mr. Ditchburn can be only productive of good." ${ }^{73}$ What is also clear, however, is that Teit was being used to some extent, and it was clearly in Scott's mind that it would be to the government's advantage to co-opt Teit, a task apparently assigned to Chief Inspector Ditchburn.

The shallowness of Scott's commitment to native rights was revealed with the passage of the British Columbia Lands Settlement Act on 1 July 1920. Signed into law as Bill 13 while Teit was being paid to study the findings of the McKenna-McBride Commission, the Act authorized implementation of the Commission, including authority to institute cut-offs of reserve land without Indian consent. It was a blatant betrayal of a long-standing promise. Teit continued his assignment of reviewing the findings of the Commission however, and there is no denunciation of the Lands Settlement Act in his correspondence.

What was Teit thinking at this point? Perhaps he was impressed by the fact that Inspector Ditchburn was more amenable than Major J.W. Clark, the provincial representative on the inquiry, to native demands for vacant crown lands, coastal fishing stations, and land covered by timber licences. ${ }^{74}$ Ditchburn and Scott may have convinced Teit, or Teit may have convinced himself, that British Columbia's native people would get a better and a quicker deal from the federal government. ${ }^{75}$ There is no doubt Teit was hoping for a settlement, because he wanted to get back to his anthropological work, a desire he had been expressing for a number of years. He was also, of course, being pressured by both Franz Boas and Edward Sapir to do so. By the end of 1920 , when he was diagnosed with cancer or a cancer-like disease, there was

71 NAC, DIA, RG 10, Vol. 3820, File 59,335 Part 3, D.C. Scott to Sir James Lougheed, 1 October 1920.

72 E. Palmer Patterson II has described O'Meara as a "single-minded fatherly zealot." See Patterson, "Arthur E. O'Meara," 98.

73 NAC, DIA, RG 10, Vol. 3820, File 59,335 Part 3, Scott to Lougheed, 1 October 1920

74 Titley, A Narrow Vision, 149.

75 Teit, for example, reported to Scott the decisions of a December 1920 meeting of the executive of the Allied Tribes. However, given that one of the resolutions of the meeting was "keeping good faith" with the federal and provincial governments, there is little justification for reading sinister motives into Teit's actions. NAC, DIA, RG 10, Vol. 3823, File 59,335-5, Teit to Scott, 13 December 1920. 
a definite sense of personal urgency in Teit's desire to see the land rights dispute settled to the satisfaction of the native people.

There can be no doubt, however, that Teit's moral earnestness, and his desire to deal with federal officials in good faith, was naive. In April 1921 W.E. Ditchburn wrote to the DIA in Ottawa, informing the secretary that Teit had been ill since December 1920, and that both Vancouver doctors and doctors at the Mayo Clinic had diagnosed him with cancer on the lower part of his abdomen. ${ }^{76}$ Ditchburn informed the secretary that Teit had already been paid for his services, and that he had written to Teit asking for the return of the balance. Ditchburn concluded by saying that Teit's name "will no longer appear on the pay-roll, his illness having destroyed any usefulness which he might have had to the Department." ${ }^{77}$

As it turned out James Teit was not yet finished making a contribution. Homer Sargent, the American philanthropist who had funded much of Teit's research for many years, paid for Teit's trip to the Mayo Clinic in Rochester and for his X-ray treatments in Vancouver. By December 1921 Teit's weight, which had fallen to 117 pounds, had returned to 154 pounds. By this time Teit was once again working hard for the native cause:

I am busy doing Ind. Department work in connection with the requirements or needs of the Indians re. farming land, irrigation water, pasture lands, fishing, hunting \&c. I dont know whether a settlement will come out of the work - it all depends whether the govts. will go far enough to really satisfy the needs of the Indians. ${ }^{78}$

By 1921, however, James Teit's ability to influence the course of events was severely restricted. The inquiry into native land rights would not be completed until 19 March 1923, several months after his death. Following his cancer diagnosis, Teit's concern turned to his anthropological work. He wrote to Franz Boas: "I am very sorry about this trouble not only on account of my wife and family but also on account of the much unfinished and unworked up anthropological work and data I have on hand. I could work up all the best of this had I even only 2 or 3 years longer to live." ${ }^{\prime 79}$ Until June 1922, when he suffered a relapse, Teit concentrated on his anthropological work and attempted to organize the data on the ethnobotany of the B.C. interior that he had been compiling for many years. In August 1922 Franz Boas wrote home from Spence's Bridge: "The visit here is very sad. An old companion of my

76 Teit had experienced serious swelling of the prostate in 1915.

77 NAC, DIA, RG 10, Vol. 8064, File 901/30-1-14, Ditchburn to Secretary, DIA, 25 April 1921.

78 APS, FBP, B:B61, Teit to Boas, 20 December 1921.

79 APS, FBP, B:B61, Teit to Boas, 11 March 1921. 
travels is dying of cancer of the bladder. I spend much time with him trying to give him courage." ${ }^{180}$ On 30 October 1922 James Teit died. When Boas heard of his death he commented: "Truly in him the Indians have lost their most faithful friend." $" 81$

This was not just the opinion of Franz Boas. In the summer of 1923 representatives of the Allied Tribes met in Vancouver with Charles Stewart, the federal Minister of the Interior. Before he began his presentation, Peter Kelly made the following statement about James Teit:

\begin{abstract}
There is one little sad reference I am compelled to make, and that is, since our last meeting on the 24th of July last year, our esteemed friend, one who has found a warm place in the heart of every Indian in this Province, has passed away. I refer to our friend, the late J.A. Tait [sic]. He was not just a friend, he was a brother of the Indians in this Province. He had their utmost confidence. He had their implicit trust; he was looked to, not as a white man, not as a sojourner among the Indians in this Province, but one of them; one who could present their views perhaps better than any other man of the present generation. ${ }^{82}$
\end{abstract}

Five years after Teit's death, Teit had not been forgotten. In the spring of 1927 representatives of the Allied Tribes appeared before a Special Joint Committee of the Senate and House of Commons. The Committee had been appointed to look into a petition submitted to Parliament in June 1926, which was the culmination of many years work in the struggle for aboriginal rights in British Columbia. In his presentation Andrew Paull drew on a document prepared by James Teit in Ottawa in 1920. After reading from the document Paull said: "Now, this was the opinion arrived at by our late friend, and we attach a great deal of importance to statements that he prepared carefully." Paull went on to have this to say about Teit's position on Bill 13, empowering the federal government to adopt the findings of the Royal Commission: "It will speak for itself, and I think it expresses the Indians' viewpoint very accurately."

In 1915 James Teit argued that objections to the potlatch were based on "prejudice, ignorance, misunderstanding, or selfishness." He went on to add:

80 "Boas to Dear Toni," 30 August 1922; quoted in Rohner, The Ethnography of Franz Boas, 277.

81 Boas, "James A. Teit," 102-3.

82 NAC, DIA, RG 10, Vol. 3820, File 59,335 Part 1, Meeting of Charles Stewart, Minister of the Interior and the Allied Indian Tribes of British Columbia, Speech of Mr. Kelly, 25 July 1923. 
It is a serious matter to destroy suddenly and by force the social, economic, and other institutions of a people. You are aiming a blow at their life, and if the blow is effective, it means their demoralization. Any white race powerful enough would fight to the bitter end against this. ${ }^{83}$

James Teit had, as his native friends recognized, a tremendous capacity to identify with them and to carry out their wishes. He fought for native rights, the enlarging of reserves, and greater native control over natural resources, but he did not presume to tell native people how they should organize their own lives. As Judith Judd Banks has pointed out, James Teit admired native people with a "positive self-image" who fought for the right to self-determination. ${ }^{84}$ Peter Kelly, Andrew Paull, and other native leaders who worked with James Teit recognized both the genuineness and the importance of his involvement. To them, what James Teit said and did was much more important than who he was. The legacy of the fight for native self-determination is a legacy they share.

I would like to thank Beth Carroll-Horrocks and the staff of the American Philosophical Society in Philadelphia for aiding my research on the Franz Boas papers. Thanks as well to Benoit Theriault at the Canadian Museum of Civilization in Ottawa for help with the Edward Sapir Papers. And a special thanks to fellow Teit enthusiasts Wendy Wickwire and Nancy Turner for their cross-Canada encouragement and support.

83 NAC, DIA, RG 10, Vol. 3629, File 6244-3, Teit to Sapir, 18 February 1915.

84 Banks, "Comparative Biographies of Two British Columbia Anthropologists," 192. 